Portland State University

PDXScholar

$1-1-2010$

\title{
Social Sustainability and Ecotourism: Rethinking Development for Social and Environmental Well- Being in the Caribbean
}

Veronica Dujon

Portland State University

Follow this and additional works at: https://pdxscholar.library.pdx.edu/soc_fac

Part of the Sociology Commons, and the Tourism and Travel Commons Let us know how access to this document benefits you.

\section{Citation Details}

Dujon, V. (2010). Social sustainability and ecotourism: rethinking development for social and environmental well-being in the Caribbean. The International Journal of Environmental, Cultural, Economic and Social Sustainability, Volume 6, Issue 3, pp.181-192.

This Article is brought to you for free and open access. It has been accepted for inclusion in Sociology Faculty Publications and Presentations by an authorized administrator of PDXScholar. Please contact us if we can make this document more accessible: pdxscholar@pdx.edu. 


\title{
Social Sustainability and Ecotourism: Rethinking Development for Social and Environmental well-being in the Caribbean
}

\author{
Veronica Dujon, Portland State University, Oregon, USA
}

\begin{abstract}
Many countries in the Caribbean are exploring ecotourism, alongside mass tourism, as a development strategy in the period following the collapse of export crop industries. Ecotourism as a strategy for economic development has produced mixed, if not disappointing, outcomes for the lives of the majority of people where it has been attempted (Honey 1999; Sinclair 1998). This article makes the argument that successful pursuit of ecotourism to promote integrated economic and social development can be enhanced when there is potential for the adverse impacts of tourism to be mitigated by the presence of certain structural domestic conditions. Using evidence from the island state of St. Lucia where a programmatic effort by the state to promote heritage tourism has been in operation for almost two decades the theoretical argument is made that ecotourism that relies on the unique structure of local ownership of productive resources, supported by technical skill supplied by the state, facilitates greater participation in the tourist sector on terms advantageous to economically and socially marginalized participants. Thus far the Programme has encouraged environmental awareness and cultural appreciation in the local population, encouraged entrepreneurial activity, and diversified entry into an enclave sector through avenues other than cheap unskilled seasonal work. The article concludes with an examination of the prospect for this effort to contribute to more widespread development policy focused on social and environmental well-being.
\end{abstract}

Keywords: Ecotourism, Heritage Tourism, Social and Economic Development, Small Island States, Human Centered Development, Caribbean

\section{Introduction}

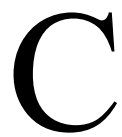

ARIBBEAN ECONOMIES HAVE struggled to define appropriate paths to economic development since the end of colonialism in the mid twentieth century (Payne and Sutton 2001). Today they seem to have all bowed to dominant neo-liberal prescriptions that encourage development through unrestricted trade. In that orientation powerful capitalist investors and the states that support them are best poised to benefit while economically challenged Third World economies remain vulnerable and relatively ineffective (McMichael 2004; Korten 1995; Griffith 1994; Watson 1994). Others have argued however, that resistance in the form of social movements and the ability to hold decision makers accountable can make a significant difference in outcomes (Sassen 1998, Panitch 1997). For many communities economic marginalization in the global economy often coupled with deteriorating environmental conditions have motivated the search for alternatives to dominant neoliberal prescriptions for development that better respond to social and environmental wellbeing, and therefore more socially sustainable (Dujon 2009; Stahler-Shock 2007; Harris 2000). This article examines evidence from the Caribbean island state of St. Lucia as it rethinks its development strategy in the tourism sector. The article makes the theoretical argu-

The International Journal of Environmental, Cultural, Economic and Social Sustainability Volume 6, Number 3, 2010, http://www.Sustainability-Journal.com, ISSN 1832-2077 
ment that ecotourism that relies on the unique structure of local ownership of productive resources supported by state supplied technical skill facilitates greater participation in the global economy on terms advantageous to economically and socially marginalized participants in the domestic economy.

In the mid twentieth century, following the end of the Second World War, and with it the end of the rule of colonial empires, newly independent developing countries motivated by aspirations for improved quality of life for their citizens were encouraged to pursue, and engaged in, nation building programs that focused heavily on development that prioritized economic growth driven by export led production. Significantly less attention was given to human-centered development. This particular path, the neoliberal model, is premised on the argument that private-sector market forms are superior mechanisms for providing for peoples' needs, and societies are best served by a reduced role for states and communal institutions in the economy. Such growth oriented development that focuses on quantitative economic change and typically measured in GDP, has long been criticized in scholarly and policy literature for failing to incorporate human well-being as a fundamental component of development, and therefore falling far short of achieving more holistic development outcomes (Harris and Goodwin 2001; OECD 2000; Harris 2000; Daly 1996). The continued application of neoliberal models following the economic devastation of the Debt Crisis of the 1980s has resulted in disastrous social and environmental consequences for the majority of poor and working people in the developing world (Bello 2004; Stiglitz 2003).

Recent evidence from social and protest movements suggests that marginalized people have made an intimate connection between the destruction of the natural environment and social and economic deterioration (Stahler-Shock 2007). In essence the push has been for greater social sustainability. Social sustainability refers to both the processes that generate social health and wellbeing now and in the future and those social institutions that facilitate environmental and economic sustainability now and for the future (Dillard et al 2009). The ability to promote the appropriate processes and social institutions is a contested process driven by different worldviews, the institutions they give rise to, and the ability of different social groups to harness political power to promote certain outcomes. The quest for social sustainability reflects the particular constraints and opportunities across place, space and time (Dujon 2009).

A majority of Caribbean islands have pursued tourism as a key component in their development portfolios, but despite the fact that the global tourist industry consistently ranks as one of the top three industries today, attempts to capture some of that value in tourism and convert it into meaningful development has been disappointing (Honey 1999; Sinclair 1998). Ownership of productive resources tends to be controlled by foreign investors who are able to negotiate extended tax holidays and the expatriation of profits. Available employment is mostly for low-skilled seasonal workers and relatively few internal linkages with domestic agricultural sectors develop since most supplies are imported.

The advent of ecotourism and the parallel decline in dominant agricultural sectors have encouraged struggling Caribbean economies to turn to eco-tourism strategies that promise to reverse that trend. As an ideal concept ecotourism derives its attraction from a combination of the gains to be made from marketing a product that exists in its natural state in specific geographic locations and the potential to make such trade ecologically and economically sustainable (UNESCO 2002). For policy planners who have long agonized over how to incorporate communities traditionally excluded from the tourist industry, ecotourism has 
emerged as a new hope, which, with appropriate planning, and significant grassroots participation, is expected to overcome past pitfalls. Whether countries can apply it successfully is still an open question.

This paper contends that in St. Lucia, the fact that all major natural resource sites - beaches, coastal zones and watershed tropical rain forests - as well as historic sites, are publicly owned, is conducive to the design of a system of controlled extraction, monitoring and income distribution, in which community groups are stakeholders and assume the responsibility of gatekeepers in product delivery and conservation. Unique conditions in the form of social capital, economic networks embedded in social ties, and a unique well established communal resource institution, coupled with technical support from state agencies may be drawn upon in defining a development strategy in ecotourism that facilitates a more equitable and viable model of economic development than previous attempts, and provides an economic buffer for the most marginal of participants. The weight of this argument rests on the findings of an investigation of the advantages of communal land tenure in St. Lucia (Dujon 1997).

The paper is organized in the following manner: the next section provides an overview of the St. Lucian experience with global integration. This is followed by a discussion of ecotourism as a development strategy. The next section lays out the basis for the argument that in the case of St. Lucia certain internal socioeconomic conditions, in particular the presence of a communal land institution that serves the needs of many marginalized citizens, may allow participants, with state support, to carve out some control over the terms of their integration into the global economy in ways that are both unexpected and more equitable.

\section{St. Lucia and Global Integration}

St. Lucia is located near the southern end of the Caribbean chain, between Martinique to the north and St. Vincent to its south. It is 238 square miles in area (616 sq. km.), and has a population of 160,000 people. The official language is English, but Patwa a French creole, is the predominant language in the rural sector. St. Lucia gained independence in 1979 and continues to be part of the British Commonwealth. Like many other ex-colonies, the country is primarily an agricultural economy based in the export of bananas, and in the last few decades has developed a tourist sector. In large part, the rapid decline of the banana sector following a trade dispute between the European Union and the United States over preferential access of African, Caribbean and Pacific fruit to the European market, arbitrated by the World Trade Organization, prompted an urgent search for economic diversification and subsequent interest in ecotourism.

Caribbean countries are faced with some of the basic economic problems that plague other developing countries. Small island states rely on the export of a few agricultural and mineral products as the main income earning activity to generate growth and development. This strategy must be implemented, however, in a global economy in which free trade is advocated and Caribbean countries find themselves increasingly unable to compete (Payne and Sutton 2001; Watson 1994; Deere et al 1990). The recent banana trade war over the European fruit market between Caribbean countries and the United States captures well the dilemma faced by small agricultural economies. The U.S. acting on behalf of U.S. companies in Central America, mounted a successful attack on British preferential trade agreements with its former colonies. Various islands, St. Lucia among them, have suddenly seen their agricultural sectors plummet as a result (Dujon 2002). Ironically, St. Lucia only a few short 
years earlier had been encouraged to expand its banana sector under a land privatization scheme.

Unlike many of its neighbors St. Lucia enjoyed positive growth rates in the mid-1980s (6.0\% in 1985 and 5.3\% in 1986), and had a debt burden observers considered manageable (St. Lucia 1987). Nevertheless, in 1986 the government of St. Lucia undertook a land registration and titling project (LRTP) as part of an initial phase of a wider agricultural structural adjustment program sponsored by USAID. Communal land tenure was the target of this LRTP on the premise that its under capitalization and low productivity could be corrected by establishing an efficient land market. This privatization effort threatened to eliminate communal land and its associated institutions that had been used as a buffer against unpredictable economic changes by small and marginal farmers (Dujon 2002).

It is important to note however, not only did the St. Lucian government insist that tenure conversion be voluntary, but that USAID agreed to this provision. In a country with a strong democratic tradition and where all major parties rely on the support of small farmers in the agricultural sector, to do otherwise would have been political suicide (Dujon 2002). There is some speculation about why USAID relented. In part, in could be in deference to the democratic tradition of the country, or perhaps the small geographic and economic size of the country, which make it relatively insignificant, afforded it some space to pursue a nontraditional path (Dujon 1995).

The communal land institution was, and continues to be, essentially a local resource used by farmers to organize assets and labor allocation in ways that benefit people traditionally disenfranchised by economic change. Ownership of the means of production and the robust line of accountability between peasant farmers and either of the two main political parties, the United Workers Party (UWP) and the St. Lucia Labour Party (SLP), facilitated a successful challenge of the privatization project and reflected the impact local social forces within the particular social formation (Dujon 2002). More recently, in the aftermath of the decline of the banana industry, demand for promoting economic growth in the rural sector encouraged the promotion of innovative ecotourism alternatives such as the St. Lucia Heritage Tourism Programme (discussed below) to incorporate marginal farmers.

\section{Ecotourism: Rethinking Development for Environmental and Social Sustainability}

The Ecotourism Society defines ecotourism as the purposeful travel to natural areas to understand the culture and natural history of the environment, taking care not to alter the integrity of the ecosystem, producing economic opportunities that make the conservation of natural resources beneficial to local people (Ecotourism Society 1991). Understandably, for countries considering ecotourism as part of a development strategy the primary emphasis is somewhat different. In Dominica, for example, the general manager of the National Development Council argued that ecotourism in that island could not be conceptualized as a huge national park in which Dominicans lived. Rather, ecotourism had to be understood first as a development tool that could provide for improved quality of life for citizens (Patrullo 1996: 126).

Smaller Caribbean territories are exploring ecotourism not to replace traditional massbased tourism, but as a complement to it. The objective is to take advantage of a growing niche in the wider global industry to diversify the portfolio of tourism activities (Brandon 1996). To that effect, the excursions into nature by tourists would be in the form of "add- 
ons." The aim is to encourage those individuals who have already decided to visit a country for various reasons to visit natural sites or to partake in indigenous culture. Such small-scale attempts at ecotourism have the advantage of not incurring any additional overhead in terms of marketing and at the same time may redefine how people in small communities can be integrated into a larger pre-existing tourist economy.

From one set of perspectives, the logic of ecotourism as a development strategy is very much like that of other non-traditional export-led strategies. Ecotourism may be conceptualized as an extractive industry with an export product. In some ways this product is like a primary agricultural product in the sense that there is little processing or value added and the product is highly vulnerable to global economic fluctuation.

However, there are obvious and significant differences in terms of identifying the product and its mode of extraction, determining sustainable levels of extraction and configuring the institutions and avenues through which benefits from the sector will be distributed. The product removed is not tangible, but over time and depending on the intensity of extraction, there is an obvious (visual and physical) depreciation or depletion of the resource directly linked to the movement of consumers who return to their places of origin. This process adversely affects not only the ecological integrity of the resource site, but the cultural integrity as well. There is a tendency for the cultural identity of communities to shift significantly in response to the consumer values of the enclave economy, resulting in a loss or removal of some of the key characteristics on which a successful ecotourism strategy depends. The consumer travels to the product site and infrastructure such as airports, harbors, lodging/hotels and access routes must be in place to facilitate extraction.

Conceived in this way, an argument can be made that the theoretical implications and pitfalls that define export extraction may also be applied to ecotourism. The market vulnerability and ensuing economic instability associated with such a product is no different from previous experience with other export-led strategies. Proposals for ecotourism must therefore assume the responsibility for providing an adequate theoretical grounding of its prospects as an alternative sustainable development strategy.

To be a successful strategy, ecotourism cannot exist or be managed as an enclave divorced from the wider economy as happened with traditional tourism. States in the developing world ultimately have a social responsibility to all their citizens. In the final analysis, the successful pursuit of an ecotourism strategy will be defined in part by two criteria: first, if lessons can be learned from the deficiencies associated with export-led strategies, previous errors may be avoided. Second, if the logic of extraction of this natural resource is appropriately understood, pertinent policy and institutions can be devised to ensure ecological, social and economic sustainability. Innovative strategies will be key.

The island territories of the Caribbean region where communal land institutions still function present a unique set of conditions to explore some innovative paths. The fact that these islands cannot hope to compete in the arena of biodiversity with territories such as Costa Rica means they must continue to rely on the traditional attractions of sand, sea, sun and culture. They are challenged therefore, to re-conceptualize a more intimate relationship between rural communities that have too often been by-passed by the traditional tourism enclave economy. 


\section{Exploring Local Potential: Communal Institutions and Ecotourism}

The viability of sustainable ecotourism strategies will be determined, in part, by the ability of local actors to effectively participate in new and creative ways as well as their ability to monitor and regulate the use of both natural and heritage sites when financial resources to do so are scarce. The presence of high levels of social capital and mechanisms for resource distribution associated with communal property resources in St.Lucia may be harnessed in defining a successful community-based ecotourism agenda that reduces inequitable income distribution, citizen alienation, and over-exploitation of resources in ways that states and market actors have limited ability to address.

Communal land often referred to as 'family land' in the Caribbean, evolved out of a legacy of plantation production in which newly freed slaves pooled resources to acquire land which was then passed on to descendants as communal land. It is unlike more traditional forms of communal land tenure in that it evolved within the context of market forms of production (plantation slavery) and an export-led plantation growth model with essential linkages to an international economy (Dujon 1997). Institutional arrangements for managing self-governing co-operative strategies among community members are well established (Dujon 1997).

Family land conforms to the definition of common property resources in which access is controlled and outsiders may be excluded. The rules of the institution are maintained by social obligations and sanctions. As a peasant form of organization designed to allocate resources, family land embodies within its social and economic structure, a response to the opportunities and constraints of the wider society within which it is located. In particular, its function as a social security system is critical in a country where the state is unable to provide such support. Unlike welfare entitlements that are granted by states and can be revoked, the fact that citizens own the means by which they acquire these services makes them essentially more secure and therefore the resources are more desirable (Dujon 2002).

Concerns about the continued economic relevance of family land and common property resource regimes in St. Lucia were settled in the late 1980s when landowners, most of them owning small tracts of land, chose not to convert to private tenure during a USAID sponsored land registration program (Dujon 1995). To the contrary, an investigation of the unexpected outcome revealed that the communal land institution continues to be vibrant and is critical to the agricultural sector both in social and economic terms. Small farmers who participate in banana export production typically combine production on both private and communal land. Since communal land cannot be alienated, in essence the risks of participating in unstable global markets are mitigated by such ownership (Dujon 1997; 1995).

A listing of its main features underscores why those who face unpredictable economic challenges were unlikely to give it up. Proof of family lineage guarantees access to perennial crops on the communal holding which ensures a subsistence survival, or supplement to other income. Communal land can only be sold if all claimants consent to it. The most marginal of members have veto power over a sale. Irrespective of how long a claimant may have been non-resident, the right to return to the holding and reactivate a claim is guaranteed. These arrangements afford, at the minimum, the security of a subsistence living to all who fall on a range of economic need (Dujon 1997).

Although it operates as an informal sector, communal land management relies on a clear set of rules, norms and practices, and its tenure status is safeguarded in the law. This relative autonomy from the state over management decisions allows members to control labor alloc- 
ation and resource distribution, yet they enjoy the stability and security afforded by legal recognition.

In this basic model of common property resources, structural flexibility associated with the institutional network sustains a broad range of needs from commercial exploitation, a base for capital accumulation and a system of social security. It has also proven itself to be a useful and adaptable economic arrangement over an extended period dating from the midnineteen century. The acquisition of communal resources has been an effective strategy for economic survival beginning with its creation during the struggles of ex-slaves to control their labor through the pursuit of the control of the means of production, followed by the production of export crops, first sugar and then bananas in the twentieth century, and as a buffer against the adverse economic consequences of integration into the global economy of the twenty-first century (Dujon 2000). Now it serves as a model for the foundation for a more participatory, equitable and sustainable form of ecotourism. Ownership of local resources that cannot be alienated shield participation in unstable global markets even as they facilitate economic opportunity and integration.

The potential for incorporating large numbers of rural residents in some form of related economic activity is significant. In St. Lucia, for example, most villages are located along the coastline and are served by one major road system. It takes a total of approximately two hours, without stops, to complete travel along the coast from one point around the island and back. From a geographical perspective all villages are easily accessible to tourists.

The recent establishment of the donor-funded, but state-run, St. Lucia Heritage Tourism Programme to promote ecotourism is distinguished by its emphasis on sustainable rural development. The explicit objective of the Programme is the diversification of the tourist sector in ways that specifically target the rural population as participants and beneficiaries. The program also recognizes that enterprise development by the poor will often be around communal assets and solicits proposals for projects from community groups. It also recognizes that for this approach to work a supportive policy framework that provides for collaborative management and for devolution of rights of use and exclusion is required (Renard 2001).

Initially the Programme tended to work with private individuals who have entrepreneurial skill and ideas. Difficulty in identifying community groups capable of organizing and managing entrepreneurial projects and with appropriate mechanisms to distribute benefits has hampered progress in that direction (Renard 2001). Little attempt however, has been made to examine resource management on communal land as a potential model for more equitable income distribution and resources protection.

In theory, the method of accessing the ecotourism products offered can be designed to be simultaneously of low social and ecological impact and financially viable. In utilizing policies that range from controlling the method of consumption to the intensity of consumption, it is argued that both ecological integrity and economic viability can be sustained (Ascher 1995). In practice, the ideal is more often than not compromised in the process of implementation. Investment and sustainability strategies are often at odds (McClaren 1998; Wight 1992). There is a strong incentive to generate income by increasing the rate of the exploitation of resources in the short run, at the expense of jeopardizing ecological sustainability in the long run.

In a review of key issues in ecotourism, Brandon (1996: i) concludes that despite wide differences in size and management of protected areas, cultures, types of ecotourism enterprises and government involvement, in the majority of cases, such projects have failed to 
live up to expectations. It is extremely difficult to protect resources and generate appropriate economic activity at the same time. How can the new strategy be made more viable and sustainable, and what are the mechanics, policy and institutional arrangements that will lead to these targets?

Successful management of common resources is critically dependent on the type of management controls adopted and the involvement of stakeholders in defining resource use and benefits distribution (Magno, unpub. 1997; Brandon 1996; Bromley, 1992; Ostrom 1990). Boo (1990) argues that in the creation of protected areas, communities of people whose livelihoods are linked to these areas should be incorporated into the ecotourism projects as managers and beneficiaries. Failure to achieve such incorporation may alienate local residents who, in turn, may resort to ecologically unsustainable use of the resources. The involvement of local communities in resource management is emerging as pivotal in achieving the primary goals of ecological sustainability and some form of democratic distribution of benefits at the local level (Honey 1999).

According to Coleman (1988), close ties to community, family, and religious affiliation are social capital because they allow economic transactions that would not otherwise take place by providing a superior enforcement mechanism other than recourse to legal action. Kinship ties on communal land in St. Lucia, and the obligations inherent in them constitute this kind of social capital (Dujon 1997). Here, the explicit concern with social equity and the ability to operate effectively outside of state supervision and monitoring are attractive features that fit well with the ecotourism agenda.

High levels of social capital in the communal land sector have encouraged mechanisms for relatively equitable resource distribution among kin and have proven successful in reducing over-exploitation of resources (Dujon 1997). The reproduction of similar cooperative associations by kin in ecotourism ventures can potentially solve similar problems in distribution of benefits and protection of resources that states and market actors have limited ability to address. If locally owned and cooperative ventures can be relied upon to protect resources, government can provide supporting services, and thereby encourage a culture of "quality control." The bureaucratic commitments are far lower than if the government did all the monitoring.

Several arguments can be made why community orientation in managing and monitoring resources and allocating benefits may prove to be more effective, efficient and equitable than a state-directed approach in which communities may lose sight of the need to accept responsibility for regulating use. Ecotourism involves trade in a non-tangible product. Unlike other export products, it is logically difficult to associate supply or production of individuals, in any concrete or measurable way. This means that innovative ways must be developed for assigning work effort and distributing gains. Granted, individuals may engage in different levels of service (tour guides etc.), or may access income through subsidiary activity such as provision of lodging or selling of crafts, but additional institutional mechanisms are required to link individual beneficiary outcomes to an interest in the conservation or sustainable ecological maintenance of the resources (Ostrom 1990). An effective instrument needs to be developed to create stakeholders and caretakers out of beneficiaries.

Direct participation in resource management that is facilitated by social networks and informal institutions allow for a common understanding of obligations and responsibilities. These in turn are enforced through sanctioning of undesirable behavior. Such participation reduces alienation, and increases support for development programs (Ascher 1995; Bromley 
1992). When direct participation is broad, more people are likely to benefit economically, reducing concerns about distribution of income generated. Failing that kind of involvement it is likely that interests external to the communities, national or global may step in and bypass the needs of the local economy (Renard 2001; Brandon 1996).

In cases where the resource is a natural, non-renewable resource, communal management institutions can also reduce unsustainable use of resources. When there is clear understanding of who has access to, or responsibility for a resource (in this case local residents) and who does not (non-residents), there is a strong incentive for those exploiting the resource to be more disposed to preservation since they will have to live with the consequences (Dujon 1997; Bromley 1992). There is also the added advantage that direct producers, who are also local residents with a stake in a healthy environment, can do the monitoring as they deliver the product.

Mangrove forests in St. Lucia, for example, were identified as one resource that has potential to attract tourists because of their unique ecosystems but local charcoal producers, however, were harvesting mangrove in a marine reserve area. Efforts that relied on strengthening the organization of local users and a community-based management system to monitor and stem the problem produced significant success (Smith and Berkes 1993).

Monitoring exploitation is nearly impossible for a state with limited resources. However, if communities can be relied upon to do it, government can provide supporting services, and thereby encourage a culture of "quality control." The bureaucratic commitments are far lower than if the government did all the monitoring. Communal institutions thus perform productive and protective functions.

Of course, perhaps many communities are not appropriately equipped with the institutional infrastructure to manage the resources and/or distribute the benefits or have the appropriate background knowledge to define their meaningful participation as stakeholders. In such cases, some form of intervention either from government or non-governmental organizations could supply the regulatory infrastructure or facilitate a process that will eventually encourage the creation of such institutions. St. Lucia has the advantage of a functioning model of communal institutional infrastructure in the rural sector that can potentially be adapted to the ecotourist sector.

\section{Conclusion}

Caribbean countries find themselves at a crossroads between an old agro-export model of economic development undermined by the end of preferential banana exports to the European Union, and a new, yet undefined, alternative in a predominantly neoliberal global economy. Past attempts at encouraging the growth of domestic industrial sectors either on an individual basis or in cooperation with regional neighbors have been disappointing. So too have the hopes that traditional tourism can generate lasting economic growth. The search for models for future development must consider appropriate strategies in which the nature of integration in the global economy limits the vulnerability of place-bound citizens to vagaries of markets even as it promotes the skills or resources of the domestic economy for economic survival and social sustainability. The need for diverse and innovative approaches cannot be overemphasized.

This paper argues that ecotourism, as a fundamentally different conceptualization of tourism that incorporates sustainability and community participation as central elements is 
also conducive to an alternative theoretical framework of development. In this framework social networks and communal institutions that have allowed generations of peasants to survive in commercial agriculture provide a model for a more participatory and equitable form of ecotourism than has been possible under traditional mass-based tourism.

Collectively owned and managed family land has proven itself to be very adaptable to changing economic circumstances over extended periods of time because of its basic ability to organize assets and labor allocation in ways that benefit rural people traditionally disenfranchised by economic change.

Conventional strategies for economic stimulation are typically preoccupied with the relationship between states and markets, and seldom with a possible institutionalized role for intermediary associations that derive their effectiveness from a long-standing ability to generate trust, participation, and equity in inhospitable market economies. Given the ongoing debate about the (in)ability of states, particularly Third world states, to shape the nature of their integration in the global economy, the fact that citizens own resources and have inalienable property rights to social protections, as they do with communal resources in St. Lucia, is clearly a demonstrable advantage that can be incorporated into similar models for ecotourism development. Identifying such advantages early on facilitates the conceptualization of a model for incorporating them into an ecotourist sector. The efforts of the St. Lucia Heritage Tourism Programme to encourage entrepreneurial activities that are conceived as communitybased endeavors are an encouraging beginning.

Policy initiatives established in the next few years will open some opportunities, and close others. Over the last few years the increasing critique of neoliberal models for economic development may be creating some space for the exploration of unconventional options without inviting the rebuke of powerful international development institutions. If there are certain development alternatives that can potentially yield unusually attractive returns, now is the time to shed light on them and explore their feasibility. The ideas discussed here provide a foundation for alternative development strategies that may go unnoticed by agencies or research focused on conventional development strategies.

\section{References}

Ascher, W. 1995 Communities and Sustainable Forestry in Developing Countries. San Francisco, CA: ICS Press. Institute for Contemporary Studies.

Bello, Walden. 2004. Deglobalization: Ideas for a New World Economy. New York: Zed Books.

Boo, E. 1990 Ecotourism: The Potentials and Pitfalls (Vol. 1). Washington, D.C.: World Wildlife Fund.

Brandon, Katrina 1996 "Ecotourism and Conservation: A Review of Key Issues." Environment Department Papers \# 033. Washington, D.C.: The World Bank

Bromley, Daniel 1992 "The Commons, Common Property and Environmental Policy" Environmental and Resource Economics 2

Coleman, James 1988 "Social Capital in the Creation of Human Capital," American Journal of Sociology Vol 94: S95-S120.

Daly, Herman. 1996. Beyond Growth: The Economics of Sustainable Development. Boston, MA: Beacon Press.

Deere, C.D. et al. 1990 In the Shadows of the Sun: Caribbean Development Alternatives and US Policy. Boulder, San Francisco: Westview Press.

Dillard, Jesse, V. Dujon, and M. King. 2009. Understanding the Social Dimension of Sustainability. Routledge/Taylor \& Francis Group. 
Dujon, V. 2009. "In the Absence of Affluence: The Struggle for Social Sustainability in the Third World" Chapter 6 in Understanding the Social Dimension of Sustainability J. Dillard, V. Dujon and M. King (eds.) Routledge 2002 "Local Actors, Nation States, and Their Global Environment: Conceptualizing Successful Resistance to the Anti-Social Impacts of Globalization" Critical Sociology 28 (No. 3) (forthcoming).

2000 "Caribbean Peasants in the Global Economy: Popular Resistance to the Privatization of Communal Land in the Twentieth Century and Beyond" Global Development Studies 2 (No. 1-2): 199-221.

1997 "Communal Property and Land Markets: Agricultural Development Policy in St. Lucia" World Development 25 (No. 9): 1529-1540.

Dujon, V.1995 unpub. Ph.D. "National Actors Against World Market Pressures: Communal Land, Privatization and Agricultural Development in the Caribbean" Madison: University of Wisconsin-Madison.

Ecotourism Society 1991 Newsletter 1 (Spring) (1).

Greider, William 1997 One World, Ready or Not: The Manic Logic of Global Capitalism. New York: Simon and Schuster.

Griffith, Winston H. 1994 “Appropriate Economic Theory for the Caribbean” pp. 31-48 in Hilbourne Watson (ed) The Caribbean in the Global Economy. Boulder, Colorado: Lynne Reinner.

Harris, Jonathan. 2000. Basic Principles of Sustainable Development: Global Development and Environment Institute, Tufts University.

Harris, Jonathan, Timothy Wise, Kevin Gallagher, and Neva Goodwin, eds. 2001. A Survey of Sustainable Development: Social and Economic Dimensions. Washington, DC: Island Press.

Honey, Martha 1999 Ecotourism and Sustainable Development: Who Owns Paradise? Washington, D.C.: Island Press.

Korten, David 1995 When Corporations Rule the World. San Francisco: Berrett-Koehler, Inc.

MacGregor, J.R. 1993"Sustainable Tourism Development" pp. 781-789 in M.A. Khan, M.D. Olson and T. Vat (eds.), VNR's Encyclopedia of Hospitality and Tourism. New York: Van Nostrand Reinhold.

Magno, Francisco A. 1997 unpub. Ph.D. "Crafting Conservation: Forestry, Social Capital, and Tenurial Security in the Northern Philippines. University of Hawaii.

McClaren, Deborah. 1998. Rethinking Ecotourism and Ecotravel: The Paving of Paradise and What You Can Do To Stop It. West Hartford, Connecticut: Kumarian Press.

McMichael, Philip 2004 Development and Social Change: A Global Perspective. Thousand Oaks (CA): Pine Forge Press.

OECD. 2001. Sustainable Development: Critical Issues. Paris, France: OECD.

Ostrom, Elinor 1990 Governing the Commons: The Evolution of Institutions for Collective Action. New York: Cambridge University Press.

Panitch, Leo. 1997. "Rethinking The Role Of The State.” In: James H. Mittelman Globalization: Critical Reflections. Boulder, Colorado: Lynne Reinner

Patrullo, Polly 1996 Last Resorts: The Cost of Tourism in the Caribbean. London: Cassell.

Payne, Anthony, and Paul Sutton 2001 Charting Caribbean Development. Gainsville: University of Florida Press.

Renard, Yves 2001 "Practical Strategies for Pro-Poor Tourism: A case Study of the St. Lucia Heritage Programme" Pro-Poor Tourism Working Paper No. 7. http://www.propoortourism.org.uk/ppt_casestudies.html: The Overseas Development Institute, The International Institute for Environment and Development and The Centre for Responsible Tourism at the University of Greenwich.

Sassen, Saskia. 1998. Globalization and Its Discontents. New York: The New Press.

Sinclair, Thea 1998 "Tourism and Economic Development: A Survey.” Journal Of Development Studies 34 (5): 51-87 
Smith, A.H. and F. Berkes 1993 "Community-based Use of Mangrove Resources in St. Lucia." International Journal of Environmental Studies 42(2/3):123-132.

Stahler-Shock, Richard, Harry E. Vanden, Glen David Kuecker. 2007. "Globalizing resistance: The New Politics of Social Movements in Latin America" Latin American Perspectives 34 (2): 5-16.

Stiglitz, Joseph 2003 Globalization and Its Discontents . New York : W.W. Norton.

UNESCO, 2002. Retrieved from: http://portal.unesco.org/en/ev.phpURL_ID=3205\&URL_DO=DO_PRINTPAGE\&URL_SECTION=201.html

Watson, Hilbourne (ed.) 1994 The Caribbean in the Global Political Economy. Boulder, Colorado: Lynne Reinner.

Wight, P. 1993 “Ecotourism: Ethics or Eco-Sell?” Journal of Travel Research 31 (3) 3-9.

\section{About the Author}

Prof. Veronica Dujon

Veronica Dujon received her bachelor's degree from the University of the West-Indies, Barbados. She received her master's and PhD degrees in Land Resources/Sociology in 1995, both from the University of Wisconsin-Madison. She is now Professor and Chair in the Department of Sociology at Portland State University. Dujon teaches, conducts research and publishes in the areas of environmental sociology with a focus on contests over declining natural resources; sociology of globalization; women in the global economy; and the tensions between national development strategies and forces of globalization. One of her major research interest areas is how to build socially sustainable societies. Among her publications are an article entitled "Local Actors, Nation States, and Their Global Environment: Conceptualizing Successful Resistance to the Anti-Social Impacts of Globalization" (Critical Sociology, 2002), and an edited volume Understanding the Social Dimension of Sustainability [Routledge 2009] on which she is a co-editor. In this volume she has a chapter entitled: "In the Absence of Affluence: The Struggle for Social Sustainability in the Third World." 